\title{
AGT Gene Product
}

National Cancer Institute

\section{Source}

National Cancer Institute. AGT Gene Product. NCI Thesaurus. Code C136722.

A protein encoded by the human AGT gene. 